HortSCIENCE 27(12):1341-1342. 1992.

\title{
'NuMex Sunglo', 'NuMex Sunflare', and 'NuMex Sunburst' Ornamental Chile Peppers
}

\author{
Paul W. Bosland \\ Department of Agronomy and Horticulture, New Mexico State University, \\ Las Cruces, NM 88003
}

Additional index words. Capsicum annuum, vegetable breeding

The New Mexico Agricultural Experiment Station announces the release of 'NuMex Sunglo', 'NuMex Sunflare', and 'NuMex Sunburst' ornamental de Arbol-type chiles. These chiles are unique in providing a source, as well as alternative colors, for making miniristras and chile wreaths. Immature fruit are green, while mature fruit of 'NuMex Sunglo', 'NuMex Sunflare', and 'NuMex Sunburst' are yellow, red, and orange, respectively. These cultivars have minature pods; ornamental chiles released earlier were of the standard size of the New Mexican chile pod (Bosland et al., 1990).

Ornamental chiles are increasingly popular as an alternative crop for New Mexico farmers. New Mexicans traditionally harvest mature-red, New Mexican-type chiles that are then tied together to make colorful ristras (Bosland et al., 1988). The ristra is often hung near the entrance of a home as a symbol of hospitality (Sais, 1989). Ristras and wreaths made with chiles are a popular tourist product in the southwestern United States.

'NuMex Sunglo', 'NuMex Sunflare', and 'NuMex Sunburst' ornamental chiles were developed at the request of New Mexico chile producers for a chile that could be used to make mini-ristras. A mini-ristra strings together chiles that are smaller than the usual New Mexican type. The mini-ristra chiles are popular as a tourist item because they are easier to transport than traditional New Mexican-type ristras. No cultivars or commercial seed have been available to fill this need.

Received for publication 23 Sept. 1991. Accepted for publication 1 July 1992. New Mexico Agr. Expt. Sta. Journal article 1628. The cost of publishing this paper was defrayed in part by the payment of page charges. Under postal regulations, this paper therefore must be hereby marked $a d$ vertisement solely to indicate this fact.

\section{Origin}

'NuMex Sunglo', 'NuMex Sunflare', and 'NuMex Sunburst' ornamental chiles were derived by pedigree breeding from U.S. Dept. of Agriculture Plant Introduction 357573, a seed source from India. They originated from open-pollinated seed that displayed high genetic diversity. Individual plants were selfpollinated in the greenhouse for five generations, then grown and evaluated in the field for 2 years. Selection was done with the objective of combining traits deemed essential to ristra use. These included mature fruit color, noncorkiness, pointed tip, round shoulder, attached calyx, appropriate fruit length and width, and a semi-determinate plant type. Two traits, pungency and flavor, were not evaluated, After the $\mathrm{S}_{5}$, seed for each accession was increased under insect-proof screened isolation cages in the field.

\section{Description}

The fruits of 'NuMex Sunglo', 'NuMex Sunflare', and 'NuMex Sunburst' are green when immature, turning yellow, red, and orange, respectively, at maturity (Fig. 1). According to the Royal Horticultural Society (1986) color chart standards, the mature fruit colors for 'NuMex Sunglo', 'NuMex Sunflare', and 'NuMex Sunburst' are yelloworange group $17 \mathrm{~A}$, red group $45 \mathrm{~A}$, and orange-red group $33 \mathrm{~B}$, respectively. The fruits dry down on the plant under the environmental conditions of southern New Mexico.

The plants have an upright, semi-determinate and nonspreading growth habit. The flower corolla is white without spots. The fruits are pendulate with an attached calyx. Leaves are sufficiently dense on the plant frame to prevent solar injury to the pods.

Fifty-fruit pod samples of 'NuMex Sunglo', 'NuMex Sunflare', and 'NuMex Sunburst' gave, respectively, pod lengths of 83.2 $\pm 0.5 \mathrm{~mm}, 72.8 \pm 10.0 \mathrm{~mm}$, and $70.5 \pm$ 


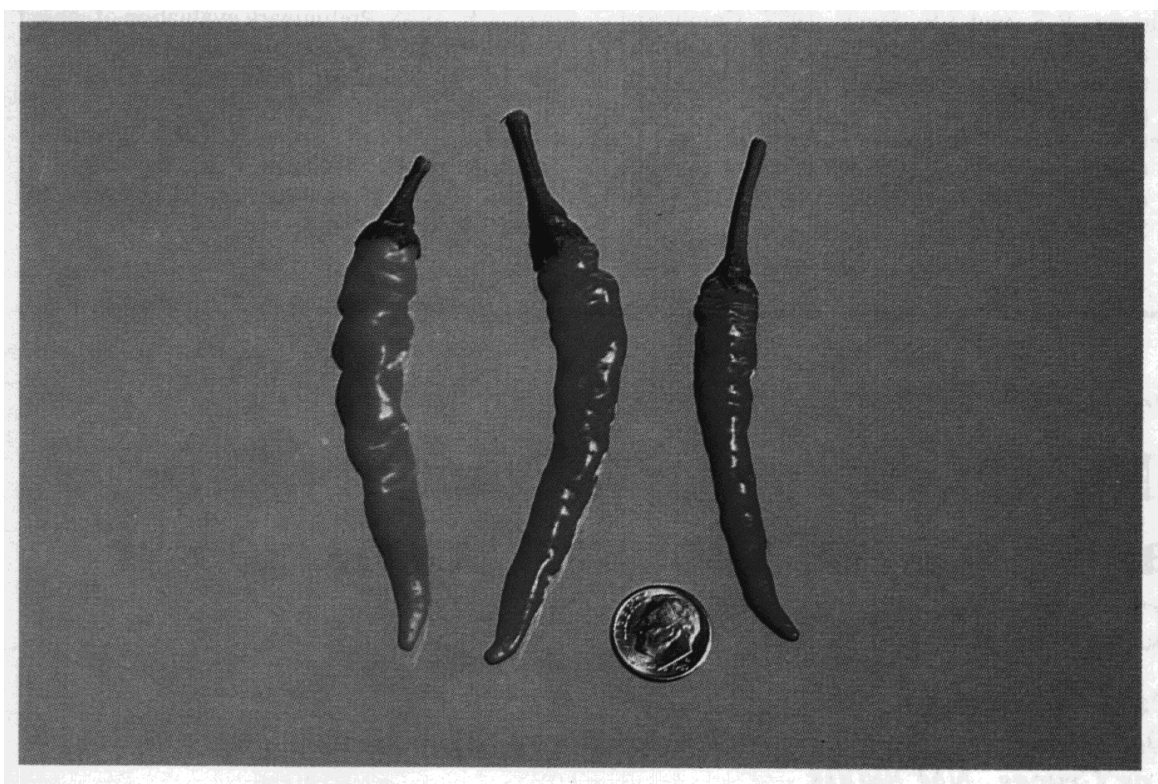

Fig. 1. Fruit of (left to right) 'NuMex Sunglo', 'NuMex Sunburst', and 'NuMex Sunflare' (coin diameter $18 \mathrm{~mm})$.

$14.9 \mathrm{~mm}$ and pod widths of $13.8 \pm 3.2 \mathrm{~mm}$, $11.9 \pm 2.0 \mathrm{~mm}$, and $12.8 \pm 2.7 \mathrm{~mm}$. These fruit sizes are in the range of pepper types known as de Arbol Chile (Bosland et al.,
1988). All three cultivars are pungent. However, the pungency level was not measured because they will only be used as ornamentals; for this reason, their flavor was not evaluated.

\section{Availability}

'NuMex Sunglo', 'Numex Sunflare', and 'NuMex Sunburst' ornamental chiles are exclusively released for commercial distribution by the New Mexico Crop Improvement Association (NMCIA). Further information is available from the NMCIA, New Mexico State Univ., Box 3CI, Las Cruces, NM 88003; phone 505/646-4125.

\section{Literature Cited}

Bosland, P.W., A.L. Bailey, and J. Iglesias. 1988. Capsicum pepper varieties and classification. New Mexico State Univ. Ext. Circ. 530.

Bosland, P.W., J. Iglesias, and S.D. Tanksley. 1990. 'NuMex Sunrise', 'NuMex Sunset', and 'NuMex Eclipse' ornamental chile peppers. HortScience 2.5(7):820-821.

Sais, J. 1989. Making chile ristras. New Mexico State Univ., Coop. Ext. Serv. Bul. 400 H-2.

Royal Horticultural Society. 1986. Royal Horticultural Society colour chart. Royal Hort. Soc. Flower Council of Holland, Leiden, Netherlands. 